\title{
A review on medicinal plants used for treating ototoxicity and acoustic trauma induced hearing loss
}

\author{
Mohammad-Reza Mahmoudian-sani ${ }^{\oplus 1}$, SomayehHashemi Sheikhshabani², \\ Farzaneh Sadat Mirfakhar ${ }^{3}$, Samira Asgharzade, ${ }^{2, *}$
}

\begin{abstract}
${ }^{1}$ Research Center of Thalassemia and Hemoglobinopathy, Health Research Institute, Ahvaz Jundishapur University of Medical Sciences, Ahvaz, Iran, ${ }^{2}$ Cellular and Molecular Research Center, Basic Health Sciences Institute, Shahrekord University of Medical Sciences, Shahrekord, Iran, ${ }^{3}$ Chronic Diseases Research Center, NOVA medical school/ Faculdade de Ciências Médicas, Universidade NOVA de Lisboa, Lisboa, Portugal.
\end{abstract}

\begin{abstract}
Hearing loss induced by chemotherapy and acoustic trauma is mainly associated with two factors, free radical formation and apoptosis pathway activation. Despite numerous efforts on reducing the effects of these factors, no definite strategy is still determined to interfere with and control these processes. In recent studies, various protective agents, including antioxidants have been used on animal models, to inhibit the formation of free radicals thus improving hearing loss.In this review article we will discuss the role of traditional herbal medicine in treatment of noise/drug induced hearing loss, focusing on medicinal plants' active substances, as well as their mechanisms of action in reducing or preventing the formation of free radicals thus increasing the rate of survival of cochlea cells. Data have been gathered since year 2000, from scientific publications including the following keywords: deafness, drug toxicity, acute trauma, medicinal herbs and oxidative stress. The study includes all herbs and medicinal plants that have been experimentally used in studies on animal models and clinical trials. The results from these studies indicate the effectiveness of most of these herbs and their active substances through their antioxidative properties. Medicinal plants reported in this review can thus be considered as effective remedies intreating noise/drug induced hearing loss,yet further studies need to be done.
\end{abstract}

Keyword: Hearing Loss/ prevention \& control. Ototoxicity. Acoustic Trauma/ physiopathology. Herbal Medicine/ instrumentation. Oxidative stress/ drug effects. Antioxidants/ therapeutic use. Hearing Loss, Noise-Induced/ therapy. Plants, Medicinal/ drug effects.

\section{INTRODUCTION}

Hearing loss is the most common neuro-sensory disorder (Asgharzade et al., 2017). Several factors are associated with the cause and exacerbation of hearing loss such as genetic mutations (Asgharzade et al., 2017), alterations in the vascular function of the auditory system, reduced oxygenation and increased reactive oxygen and nitrogen species (Melgar-Rojas et al., 2015). Formation of reactive oxygen species (ROS) and reactive nitrogen species (RNS) is the main factor involved in the pathophysiological mechanisms of cochlear damage inducedby ischemia, ototoxicity, and noise

\footnotetext{
*Correspondence: S. Asgharzade. Cellular and Molecular Research Center, Basic Health Sciences Institute, Shahrekord University of Medical Sciences, Shahrekord, Iran. Tel: +98 38 33331471Mob: +989132802336. E-mail: Asgharzade.s@skums.ac.ir; Asgharzade2336@gmail.com
}

(Huang et al., 2000). The presence of highly reactive oxygen and nitrogenspecies is essential for survival of the cells. However, increased amounts of these reactive species can damage various cell organelles. Studies have shown that mitochondria are the main source of active reactive oxygenspecies in response to hypoxia-ischemia. Superoxide radicals (super $\mathrm{O}_{2}$ ) react with nitric oxide (NO) and create toxic peroxynitrateanions (Huang et al., 2000; Asgharzade et al., 2015). Superoxide also convertsto inactive form of $\mathrm{H}_{2} \mathrm{O}_{2}$ through superoxide dismutase (SOD), and the resulting $\mathrm{H}_{2} \mathrm{O}_{2}$ further converts to $\mathrm{OH}$ reactive radicals by iron-catalyzed Fenton's reaction. These toxic compounds can damage cell biomolecules such as lipids, proteins and DNA (Kurabi et al., 2017). Chemotherapy drugsand glycosylated antibiotics administration and exposure to noise can damage the auditory system by increasing the production of ROS and 
RNS and activating the apoptotic pathway in cochlea cells. Antioxidant properties of Medicinal plants can inhibit ROS and RNS as well as the apoptosis pathway therefore medicinal plants would make an effective complimentary drug option to reduce adverse effects of common ototoxic medications (Rabiei et al., 2015; Mahmoudian-Sani et al., 2017a). Various studies have examined the simultaneous use of ototoxic drugs and various medicinal plants. This review article intends to focus on different medicinal plants used to treat hearing loss (induced by ototoxic drugs and noise) as well as their protective mechanism in the auditory system.

\section{OTOTOXICITY}

Ototoxicity is a chemical/drug induced tissue degeneration of the inner ear, caused by several therapeutic medicines. Such damage can lead to vestibular function impairment and temporary or permanent hearing loss or ototoxic substances that are commonly used in clinics include aminoglycoside and macrolide antibiotics, chemotherapy drugs such as cisplatin and carboplatin, antimalarial drugs and loop diuretics (Kalinec et al., 2017).

\section{OTOTOXICITY OF AMINOGLYCOSIDES}

Aminoglycoside antibiotics are commonly used to treat infections such as tuberculosis, bacterial endocarditis and pneumonia. Application of these antibiotics causes hearing loss $(>33 \%)$ and vestibular toxicity (>15\%) in patients (O'Sullivan et al., 2017). Yet, these drugs are still used in developing countries due to the low price (Mahmoudian-Sani et al., 2017b). Aminoglycosides rapidly penetrate into the cochlear tissue after systemic administration (Jiang, Karasawa, Steyger, 2017). Although the drug concentration is similarin blood plasma and in inner ear, it remains in the inner ear for longer period of up to 6 months (Huthet al., 2015). Therefore, a previous aminoglycoside therapy increases the chance of ototoxicity in patients Long-term exposure of cochlear cells to aminoglycosides induces outer sensory hair celldeath of vestibular organ thus auditory nerve damage. The degree of damage is directly related to the dosage and duration of application of this drug. Increased hair cell damage subsequently leads to hearing loss. Aminoglycosides form a complex with iron after entering the cell and catalyze unsaturated fatty acids to produce ROS. The ROS initiates the apoptosis pathway and necrotic cell death (Figure 1) (Ciorba et al., 2013). One of the pathways activated by aminoglycoside via ROS is the c-Jun N-terminal kinase (JNK) pathway which is alsoinvolved in cell apoptosis (Davis, 2000). By controlling the JNK pathway, cochlear cells can be protected against neomycin-induced ototoxicity (Chang-Chien et al., 2017). One of the downstream targets of JNK is activating protein-1 transcription factor. Gentamicin applies its ototoxicity effect to the outer hair cells via increasing the activity of this transcription factor (Steyger et al., 2018).
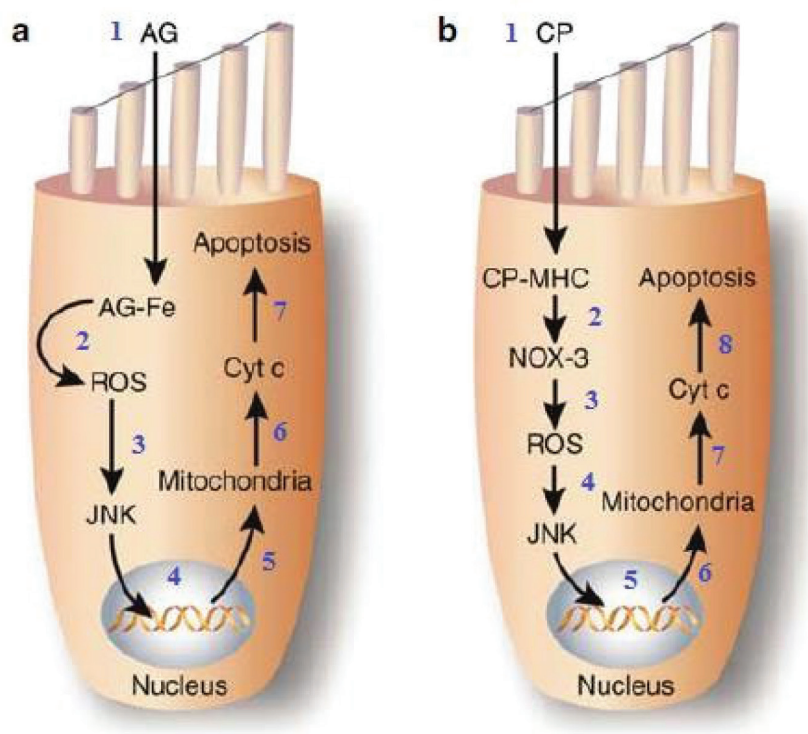

FIGURE I - The mechanism of induction of external hair follicles by cisplatin and aminoglycosides. a) Aminoglycoside (AG): 1) Aminoglycoside entry through Mechanotransducer canals; 2) The reaction of the iron-aminoglycoside complex with arachidonic acid and the formation of ROS; 3 ) activating the JNK pathway by ROS; 4) Transcription of active genes in the cellular death pathway; 5) starting mitochondrial pathway apoptosis; 6) Cytokram release, targeting capepase pathway via caspase; 7) Cell death. b) Cisplatin (CP): 1) Cysplatin entry through Mechano transducer canals $\mathrm{CP}$ within cells can beequated to form the monohydrate complex (MHC), which is more; 2) Highly reactive; 3) Activating NOX-3 with CP or MHC and producing ROS; 4) Activating JNK pathway by ROS; 5) Transcribing active genes in the cellular death pathway; 6) staring of mitochondrial-dependent apoptosis; 7) Cytokram release, targeting the pathway of apoptosis through caspase; 8) Cell death.

\section{CISPLATINIC OTOTOXICITY}

Cisplatin is a chemotherapeutic agentto treat a variety of cancers including ovarian, testicular, bladder, cervical and lung cancers The platinum atom of cisplatin forms a covalent bond with the N7 position of purines in DNA, and the damage activates MAPK/JNK/ ERK signaling pathways (Davis, 2000). Cisplatin induces 
cell death in cancerous cells through two mechanisms, namely apoptosis and necrosis. The occurrence of either mechanism is dose dependent, high doses of drug leads to cell death through necrosis while lower doses induce apoptosis pathway.

Cisplatin administration has been restricted due to renal toxicity, neurotoxicity and ototoxicity (Wang, Lippard, 2005) and severe hearing loss may occur in approximately $75-100 \%$ of patients after high-dose chemotherapy (Rybak and Ramkumar, 2007). The early stages of drug administration, hearing loss is usually bilateral at high frequencies but it progresses to lower frequencies as treatment continues. Cisplatin affects three areas of the cochlear including cortical limb cells, spiral ganglion cells and lateral wall tissue (spiral ligament and StriaVascularis). It then enters hair cells to produce ROS (Rybak, Ramkumar, 2007).ROS increases the calcium influx in the cochlear cells and induces apoptosis. The increase in NADPH Oxidase 3 (NOX3) expression was observed when treating rats with Cisplatin. NOX3 boosts the production of superoxide $\left(\mathrm{O}_{2}^{-}\right)$and hydrogen peroxide $\left(\mathrm{H}_{2} \mathrm{O}_{2}\right)$ compounds which react with unsaturated fatty acids in thecell membrane to produce highly toxic aldehydes. Superoxides also react with nitric oxide (NO) to form proxy nitrite which in turn reacts with proteins to produce nitrotyrosine (Mukherjea et al., 2006). Finally, through activating the downstream pathways, these radicals activate the apoptosis pathway in the hair cells and spiral ganglion cells (Figure 1) (Steyger et al., 2018).

\section{NOISE-INDUCED HEARING LOSS}

Up until a decade ago, the main cause of hearing loss was believed to be the mechanical destruction of the subtle hair cell membrane and the supportive structure of the cortex as well as an alteration in blood flow into the inner ear as a result of severe noise (Fetoni et al., 2015). Studies show that exposure to noise leads to increased production

TABLE I -The list of medicinal plants used to treat ototoxicity induced by gentamicin, cisplatine and noise in the warld

\begin{tabular}{|c|c|c|c|c|c|c|}
\hline Latin Name & Part used & Medicinal uses & $\begin{array}{c}\text { Geographical } \\
\text { Regions }\end{array}$ & $\begin{array}{c}\text { Deafness } \\
\text { Experimental }\end{array}$ & $\begin{array}{c}\text { Functional } \\
\text { Pathway }\end{array}$ & Refrence \\
\hline Radix astragali & Root & $\begin{array}{l}\text { Chronic fatigue } \\
\text { syndrome } \\
\text { Candidiasis } \\
\text { Herpes simplex } \\
\text { virus } \\
\text { Hypoglycemia } \\
\end{array}$ & Chinese & Acoustic trauma & $\begin{array}{c}\text { inhibiting the } \\
\text { down-regulation } \\
\text { of connexin } 26 \text { and } \\
\text { KCNQ1 } \\
\text { Antioxidant against } \\
\text { free radicals } \\
\end{array}$ & $\begin{array}{l}\text { (Xiong et al., } \\
\text { 2012a; } \\
\text { Xionget al., } \\
\text { 2015) }\end{array}$ \\
\hline Gushen pian & - & $\begin{array}{l}\text { Splenonephric } \\
\text { Hypofunction } \\
\text { phlegm } \\
\text { Accumulation stasis }\end{array}$ & Chinese & $\begin{array}{l}\text { Clinical trial II } \\
\text { Sensorineural } \\
\text { deafness } \\
\text { Tinnitus } \\
\end{array}$ & - & $\begin{array}{c}\text { (Zhai, Fang et al., } \\
\text { 2013) }\end{array}$ \\
\hline Korean red ginseng & Root & $\begin{array}{c}\text { Diabetes immune } \\
\text { enhancement }\end{array}$ & Korean & $\begin{array}{c}\text { 3-Nitropropionic } \\
\text { acid } \\
\text { Gentamicin } \\
\text { Cisplatine } \\
\text { Loud noise } \\
\end{array}$ & $\begin{array}{l}\text { Antioxidants against } \\
\text { free radicals }\end{array}$ & $\begin{array}{c}\text { (Tian et al., } \\
\text { 2013) }\end{array}$ \\
\hline $\begin{array}{c}\text { Astragalus } \\
\text { membranaceus }\end{array}$ & Root & $\begin{array}{l}\text { Allergic rhinitis } \\
\text { Diabetes }\end{array}$ & Chinese & $\begin{array}{l}\text { Impulse noise } \\
\text { Cisplatine }\end{array}$ & $\begin{array}{l}\text { Antioxidants } \\
\text { inhibiting the } \\
\text { apoptosis of cochlear } \\
\text { cells through the } \\
\text { suppression of ROS }\end{array}$ & $\begin{array}{l}\text { (Xiong et al., } \\
\text { 2012b) }\end{array}$ \\
\hline Maytenus ilicifolia & Leaves & $\begin{array}{l}\text { Inhibits tumors } \\
\text { Detoxifies } \\
\text { Gastric ulcers }\end{array}$ & Brazil & Cisplatin & $\begin{array}{l}\text { Antioxidants against } \\
\text { free radicals }\end{array}$ & $\begin{array}{c}\text { (Kasse et al., } \\
\text { 2008) }\end{array}$ \\
\hline Salvia miltiorrhiza & $\begin{array}{l}\text { Root } \\
\text { rhizome }\end{array}$ & $\begin{array}{l}\text { Cerebrovascular } \\
\text { Disorders, } \\
\text { angina Pectoris } \\
\text { Hypertension } \\
\text { Diabetes }\end{array}$ & Chinese & $\begin{array}{l}\text { Aminoglycoside } \\
\text { Gentamicin }\end{array}$ & $\begin{array}{l}\text { Antioxidants against } \\
\text { free radicals }\end{array}$ & $\begin{array}{l}\text { (Wang et al., } \\
\text { 2003) }\end{array}$ \\
\hline
\end{tabular}


TABLE II - The list of Active Components ofmedicinal plants used to treat ototoxicity induced by gentamicin, cisplatine and noise in the world

\begin{tabular}{|c|c|c|c|c|c|c|}
\hline Active Components & Materials Constructive & Medicinal uses & $\begin{array}{l}\text { Geographical } \\
\text { regions }\end{array}$ & Experimental use & Functional Pathway & Reference \\
\hline $\begin{array}{l}\text { Wu-Ling-San } \\
\text { (blackish-brown pill) }\end{array}$ & $\begin{array}{c}\text { Poria Rhizoma } \\
\text { Alismatis } \\
\text { Polyporus } \\
\text { Cortex Cinnamomi } \\
\text { Rhizoma Atractylodis } \\
\text { Macrocephalae }\end{array}$ & $\begin{array}{l}\text { Vomiting, Diarrhea } \\
\text { Edema, Abdominal } \\
\text { Distension }\end{array}$ & Chinese & $\begin{array}{l}\text { Clinical trialII } \\
\text { Acute low-tone } \\
\text { Sensorineural } \\
\text { hearing loss }\end{array}$ & - & $\begin{array}{l}\text { (Okada, et al., } \\
\text { 2012) }\end{array}$ \\
\hline $\begin{array}{l}\text { Astragaloside IV } \\
\qquad\left(\mathrm{C}_{41} \mathrm{H}_{68} \mathrm{O}_{14}\right)\end{array}$ & $\begin{array}{l}\text { Astragalus } \\
\text { membranaceus }\end{array}$ & $\begin{array}{c}\text { Anti-inflammatory } \\
\text { Antibacterial } \\
\text { Cardioprotective } \\
\text { Neuroprotective }\end{array}$ & Chinese & Impulse noise & $\begin{array}{l}\text { Decreased the } \\
\text { expression of ROS } \\
\text { iNOS and Cas-3 }\end{array}$ & $\begin{array}{l}\text { (Xiong et al., } \\
2012 \text { b) }\end{array}$ \\
\hline Purple Bamboo salt & sea salt and bamboo & $\begin{array}{c}\text { Anti-allergic } \\
\text { Antiinflammatory }\end{array}$ & Korean & Cisplatin & $\begin{array}{c}\text { Inhibited expression } \\
\text { IL-6 } \\
\text { Suppressed } \\
\text { cytochrome c, } \\
\text { caspase-3 }\end{array}$ & $\begin{array}{l}\text { (Myunget al., } \\
\text { 2011) }\end{array}$ \\
\hline Carboxy Alkyl Esters & $\begin{array}{l}\text { Uncariato mentosa } \\
\text { Cat's claw }\end{array}$ & $\begin{array}{l}\text { Arthritis, Allergies } \\
\text { Asthma, Diabetes }\end{array}$ & America & Noise & $\begin{array}{c}\text { Antioxidant } \\
\text { protection } \\
\text { DNA repair } \\
\text { Anti-inflammation } \\
\end{array}$ & (O’Neil et al., 2011) \\
\hline $\begin{array}{c}\text { Bojungikgitang, } \\
\text { Banhabaek } \\
\text { chulchonmatang }\end{array}$ & $\begin{array}{c}\text { Astragali Radix } \\
\text { White Ginseng } \\
\text { Atractylodes rhizome } \\
\text { Glycyrrhizae Resina } \\
\text { Fraxini Cortex } \\
\text { Cimicifugae Rhizoma } \\
\text { Bupleuri Radix }\end{array}$ & $\begin{array}{c}\text { Tinnitus } \\
\text { Allergic Rhinitis }\end{array}$ & Korean & $\begin{array}{l}\text { Clinical trial II } \\
\text { Tinnitus }\end{array}$ & $\begin{array}{c}\text { Antioxidants } \\
\text { against free radicals }\end{array}$ & $\begin{array}{l}\text { (Kim et al., } \\
\text { 2010) }\end{array}$ \\
\hline
\end{tabular}

Received for publication on $21^{\text {st }}$ April 2018. Accepted for publication on $27^{\text {th }}$ June 2018

of free radicals in mitochondria, reduced cochlear blood flow, excitotoxicity, and eventually apoptosis and necrosis of the cortex (Fetoni et al., 2015). Exposure to noise for 1 to 2 hours leads to a fourfold increase of hydroxyl radicals, which causes severe DNA damage. Noise induces production of free radicals in StriaVascularis (marginal cells) and outer hair cells, and these free radicals are the main cause of reduced blood flow to the cochlea, which may in turn induce ischemia, which in turn stimulates production of free radicals (Fetoni et al., 2015). Lipids are the main biological compounds of the cell membrane, the peroxidation of which is easily initiated by $\mathrm{OH}$ free radicals. This initial reaction can trigger multiple oxidative stress chain reactions, ultimately leading to hair cell damage and death (Le Prell et al., 2007).

Loud sound exposure increases the number and spread of phagocytes-special resident macrophages in the spiral ligaments, StriaVascularis, and optic capsules; activates the transcription factor of NF-KB; and regulates the expression of the proinflammatorygenes such as tumor necrosis factor $(\mathrm{TNF} \alpha)$ and interleukin 1 beta (IL-1 $\beta$ ) in the cochlea (Watson et al., 2017).

\section{EFFECTIVE HERBS IN HEARING LOSS}

\section{Radix astragali}

Radix astragali (RA) is a traditional Chinese herbal medicine. The foliage of Rahas antioxidant properties and is widely used to treat organ damages caused by ROS. Studies have shown that RA reduces symptoms of ROS-induced ischemia in myocardial ischemia reperfusion in rats. Also, simultaneous administration of RA with cisplatin reduces ototoxicity through inhibition of apoptosis in hair cells (Xiong et al., 2015). Experiments modeling acoustic trauma induced hearing loss in guinea pigs showed that RA improves auditory function by inhibiting ROS and nitric oxide in cochlear cells. 
Gap junction proteins such as connexin 26 (Cx26) and potassium voltage-gated channel subfamily Q member1 (KCNQ1) play important roles in the intracellular signaling and potassium metabolism in StriaVascularis (SV) cells. ROS reducing intercellular coupling in cochlea by inhibiting Cx26 gene expression. RA has a protective role by reducing inhibition of CX26 and KCNQ1expression in SV cells, therefore reducing brainstem hearing impairment and SV cell damage. (Xiong et al., 2012a; Xiong et al., 2015).

\section{Gushen pian}

Gushen pian is a traditional Chinese medicine obtained from four different herbs: Drynariafortunei, Danshen, CalcinedCi Shi and Glycyrrhiza. This herbal medicineis akidney and spleen enhancer, moister andstasis eliminator, blood circulation promoter and obstructions remover. Early studies showed that Gegen, Danshen and Drynaria fortune can prevent otoxic effects of drugs by increasing blood circulation in the cochlear (Zhai et al., 2013). Gushen Pian is effective in treating sensor neuronal hearing loss, tinnitus and pressure in the ear caused by decreased activity of splenonephric and mucus accumulation. Clinical trials confirmed the non-toxicity of this herbal medicine (Zhai et al., 2013).

\section{Korean Red Ginseng}

Ginseng isaherbal remedy used for over 5,000 years. The main ingredient of this drug is Ginsenoside or Ginseng Saponins. Based on the structural difference, there are three main groups of Ginseng, Panaxadiol, Panaxatriol, and Oleanolic acid (Tachikawa et al., 1999). Korean Red Ginseng (KRG) is a biological drug produced by a Korean company from Ginseng. This product is mainly composed of Panaxadiol Saponins extracted from roots $(70 \%)$ and root hairs (30\%) of 6 year mature Ginseng plant (Jee et al., 2014). KRG is known as a non-toxic drug with anti-cancer, anti-inflammatory, antioxidant gastric ulcer protective, and anti-Alzheimer properties. It also has protective effects against the ototoxic damage caused by cisplatin, gentamicin and acoustic trauma (Hong, Lyu, 2011).Ginseng extract reduces apoptosis in internal and external hair follicles in the cortex, saccharum, and etricol by stimulating the production of superoxide dismutase and inhibiting the production of free radicals and lipid peroxidase due to cisplatin, as well as inhibition of caspase 3 and poly adenosine diphosphate polymerase ribosomes (Tian et al., 2013). KRG also showed to have protective effect in acute cochlear injuryin mouse models (induced by intra-tympanic injection of 3-nitropropionic acid) by restoring the function of fibrocytes. Spiral ligament fibrocyteplay a significant role in maintaining the cochlear's function through cortical limb cells and spiral ganglion cells. As a result, protection and regeneration of fibrocytes in spiral ligament can be protective measure against 3-NP induced hearing loss (Tian et al., 2013).

\section{Astragalus membranaceous}

Astragalus membranaceous (AM) is another typical Chinese antioxidant herb commonly used in treating ROS induced damages in various organs. Astragaloside IV is one of the major active compounds isolated from AM. (Xiong et al., 2012b). Due to its antioxidant properties, this compound prevents the formation of ROS and initiates apoptotic pathways in cochlea cells. Studies have shown that this combination also inhibits iNOS and forms reactive nitrogen species which reduce NO production and preventhair cell damage in Indian guinea pigmodels of noise-induced hearing loss (Xiong et al., 2011).

\section{Uncaria tormentosa}

Uncaria tormentosa (UT) or cat's clawis a multipurpose herbal remedy cultivated in South America and used for more than 2000 years by ancient civilizations such as Amazonian Indians Tian et al., 2013).Carboxy Alkyl Esters (CAE) are the bioactive compounds found in UT. Many studies have been conducted on the otoprotection property of CAE. In rat modes of noise induced hearing loss, CAE protects cochlea from inflammation by inhibiting TNF- $\alpha$ and IL- $1 \beta$ production via alteration in NF-kB expression pattern.it also prevents apoptosis pathway and ROS and RNS formationin hair cells via its antioxidant property (O'Neil et al., 2011). CAE supplementation has been shown to repair noise induced DNA damaged in less than 3 hours. Its dose dependent properties have also been confirmed in experiments (Sheng, Pero, Wagner, 2000). As a result, CAE with its antioxidant, anti-inflammatory and DNA repair properties mayimprove the damaged sensory nerve cells function.

\section{Tanshinone (Salviae militiorrhizae)}

Salviae militiorrhizae (SM) known as Chinese sage is a traditional Chinese medicine. It is used in treating angina and cerebrovascular abnormalities. This plant has a high antioxidant property. Studies have shown that SM has a protective role against lipid peroxidation in vitro and ototoxicityin vivo. In fact, $\mathrm{SM}$ is the potential 
antidote against free radical-induced disorders. It has shown to have otoprotective properties in mouse models of aminoglycoside-induced deafness. SM inhibits peroxidation of gentamicin-based lipid, superoxide, and radical hydroxyl by increasing the activity of intrathoracic enzymes such as superoxide dismutase, glutathione peroxidase, and catalase (Lee, Cho, 2015).

\section{DISCUSSION AND CONCLUSION}

Both cisplatin and aminoglycoside drugs cause neural-sensory hearing loss at high frequencies, which is accompanied by the loss of outer hair cells in the basal turn of the cochlea (Rybak, Ramkumar 2007; Xiong et al., 2015). Both drug groups play a role as an early stimulus for cell damage and cell death through increased oxidative stress in the ear. The main mechanism of neural-sensory cell damage by cisplatin is through the apoptosis pathway, while for aminoglycosides, it appears to be via the induction of both apoptosis and necrotic pathways. Experimental studies on animals have shown that different types of antioxidants can reduce the ototoxicity caused by aminoglycosides or cisplatin without any interference with drug effectiveness and thus appear as promising therapeutic agents.(Kim et al., 2010; Okada et al., 2012) In this regard, reported in several studies the positive effects of the medicinal herbs such as Korean Red Ginseng (Tian et al., 2013), Astragalus membranaceus (Xiong et al., 2011), Maytenus ilicifolia (Kasse et al., 2008), and Astragaloside IV (Xiong et al., 2011) on the reduction of cisplatin induced ototoxicity by, and others such as Salvia miltiorrhiza (Wang et al., 2003) and Korean Red Ginseng (Tian et al., 2013) on the reduction of aminoglycosides induced ototoxicity. Most plants inhibit the formation of free radicals of ROS and RNS due to their antioxidant properties and prevent the activation of the apoptosis pathway in the cochlea hair cells by inhibiting Caspase 3. Anumber of herbal remedies use other mechanisms to improve hearing loss. Radix astragali prevents hearing loss caused by acoustic trauma through inhibiting the reduction of Connexin 26 and KCNQ1 gene expression in StriaVascularis (Xiong et al., 2015). CAE prevents noise-induced hearing loss through its antioxidant, anti-inflammatory, and DNA repair mechanisms (O’Neil et al., 2011). Purple Bamboo Salt is used to treat tinnitus and cisplatin induced hearing loss from (Hong, Lyu, 2011). This compound has an anti-inflammatory property and prevents inner and outer hair cell death, preventing the release of cytochrome $\mathrm{C}$ and caspase- 3 and inhibiting inflammatory factors. The main focus of this article was to review the important role of medicinal herbs in treating ototoxicity induced by chemotherapy drugs and aminoglycosylated antibiotics, as well as noise induced hearing loss. Many studies have been conducted so far on animal experimental models that confirm the positive effects of these herbal extracts and derivatives on hearing loss, thus it is suggested to investigate in future the use of these herbs more extensively in clinical trialswith regard to drug-related adverse effects and antioxidant properties of medicinal plants, these herbal remedies should be embraced as natural medicine for human use.

\section{COMPLIANCE WITH ETHICAL STANDARD}

Disclosure of potential conflicts of interest: Authorsdeclare no conflict of interest for manuscript entitled:

\section{ACKNOWLEDGMENTS}

The authors would like to acknowledge Research and Technology Deputy of Shahrekord University of Medical Sciences for supporting this study.

\section{REFERENCES}

Asgharzade S, Rafieian-Kopaei M, Mirzaeian A, Reiisi S, Salimzadeh L.Aloe vera toxic effects: expression of inducible nitric oxide synthase (iNOS) in testis of Wistar rat. Iran J Basic Med Sci. 2015;18(10):967-73.

Asgharzade S, Tabatabaiefar MA, Modarressi MH, Ghahremani MH, Reiisi R, Tahmasebi P, Abdollahnejad F, et al. A novel TECTA mutation causes ARNSHL. Int J Pediatr Otorhinolaryngol. 2017;92:88-93

Chang-Chien J, Yen YC, Li SY, Hsu TC, Yang JJ.Ferulic acidmediated protection against neomycin-induced hair cell loss in transgenic zebrafish. J Funct Foods. 2017;28:157-67.

Ciorba A, Bianchini C, Pastore A, Mazzoli M.Pathogenesis of tinnitus: any role for oxidative stress. Int Adv Otol. 2013;9(2):249-54.

Davis RJ. Signal transduction by the JNK group of MAP kinases. Cell. 2000;103(2):239-52.

Fetoni AR, Eramo SLM, Paciello F, Rolesi R, Troiani D, Paludetti G. Role of antioxidant supplementation in preventing noise induced hearing loss. Hear Balance Commun. 2015;13(4):160-5. 
Hong CE, Lyu SY. Anti-inflammatory and anti-oxidative effects of Korean red ginseng extract in human keratinocytes. Immune Network. 2011;11(1):42-9.

Huang T, Cheng AG, Stupak H, Liu W, Kim A, Staecker H, Lefebvre PP, Malgrange B, Kopke R, Moonen G, Van De Water TR. Oxidative stress-induced apoptosis of cochlear sensory cells: otoprotective strategies. Int J Dev Neurosci. 2000;18(2/3):259-70.

Huth ME, Han KH, Sotoudeh K, Hsieh YJ, Effertz T, Vu AA, et al. Designer aminoglycosides prevent cochlear hair cell loss and hearing loss. J Clin Invest. 2015;125(2):583-92.

Jee HS, Chang kh, Park SH, Kim KT, Paik HD. Morphological characterization, chemical components, and biofunctional activities of Panax ginseng, Panax quinquefolium, and Panax notoginseng roots: a comparative study. Food Rev Int. 2014;30(2):91-111.

Jiang M, Karasawa T, Steyger PS. Aminoglycoside-induced cochleotoxicity: a review. Front Cell Neurosci. 2017;11(art 308):1-14.

Kalinec GM, Lomberk G, Urrutia RA, Kalinec F . Resolution of cochlear inflammation: novel target for preventing or ameliorating drug-, noise-and age-related hearing loss. Front Cell Neurosci.2017;11(art 192):1-24.

Kasse CA, Cruz OL, Iha LC, Costa HO, Lopes EC, Coelho F. The use of Maytenus ilicifolia to prevent cisplatin-induced ototoxicity. Rev. Bras. Otorrinolaringol. 2008;74(5):712-7.

Kim NK, Lee DH, Lee JH, Oh YL, Yoon IH, Seo ES, Lee CH. Bojungikgitang and banhabaekchulchonmatang in adult patients with tinnitus, a randomized, double-blind, three-arm, placebocontrolled trial-study protocol. Trials . 2010;11(1 art 34):1-7.

Kurabi A, Keithley EM, Housley GD, Ryan AF, Wong ACY. Cellular mechanisms of noise-induced hearing loss. Hearing Res. 2017;349:129-37.

Le Prell CG, Yamashita D, Minami SB, Yamasoba T Miller JM. Mechanisms of noise-induced hearing loss indicate multiple methods of prevention. Hearing res. 2007;226(1/2):22-43.

Lee SE, Cho SI. Anti-inflammatory effects of Salviae miltiorrhizae Radix extract on RAW264. 7 cell. via antioxidative activities. Korea J Herbol. 2015;30(4):89-94.
Mahmoudian-Sani MR, Hashemzadeh-Chaleshtori M, Asadi-Samani M, LutherT.A review of medicinal plants for the treatment of earache and tinnitus in Iran.Int Tinnitus J. 2017a;21(1):44-9.

Mahmoudian-Sani MR, Hashemzadeh-Chaleshtori M, AsadiSamani M, Yang Q. Ginkgobiloba in the treatment of tinnitus: an updated literature review. Int Tinnitus J. 2017b;21(1):58-62.

Melgar-Rojas P, Alvarado JC, Fuentes-Santamaría V, Juiz JM. Cellular mechanisms of age-related hearing loss. In: Miller J, Le Prell CG, Rybak L, editors. Free Radicals ENT Pathology. Chem: Human Press;2015. p.305-33.[Oxidative stress in applied basic research and clinical practice].

Mukherjea D, Whitworth CA, Nandish S, Dunaway GA, Rybak LP, Ramkumar V. Expression of the kidney injury molecule 1 in the rat cochlea and induction by cisplatin. Neuroscience. 2006;139(2):733-40.

Myung NY, Choi IH, Jeong HJ, Kim HM. Ameliorative effect of purple bamboo salt-pharmaceutical acupuncture on cisplatininduced ototoxicity. Acta Otolaryngol. 2011;131(1):14-21.

O’NeilWG, Gearhart CA, Fulton S, Fechter LD. Carboxy alkyl esters of Uncaria tomentosa augment recovery of sensorineural functions following noise injury. Brain res. 2011;1407:97-106.

O'Sullivan ME, Perez A, Lin R, Sajjadi A, Ricci AJ, Cheng AG. Towards the prevention of aminoglycoside-related hearing loss. Front Cell Neurosci. 2017;11(art 325):1-14.

Okada K, Ishimoto S, Fujimaki Y, Yamasoba T. Trial of Chinese medicine Wu-Ling-San for acute low-tone hearing loss. ORL J Otorhinolaryngol Relat Spec. 2012;74(3):158-63.

Rabiei Z, Mokhtari S, Asgharzade S, Gholami M, Rahnama S, Rafieian-kopaei M.Inhibitory effect of Thymus vulgaris extract on memory impairment induced by scopolamine in rat. Asian Pac J Trop Biomed. 2015;5(10): 845-51.

RybakL, Ramkumar V.Ototoxicity.Kidney Int. 2007;72(8):9315 .

Sheng Y, Pero R, Wagner H. Treatment of chemotherapyinduced leukopenia in a rat model with aqueous extract from Uncaria tomentosa. Phytomedicine. 2000;7(2):137-43.

Steyger PS, Cunningham LL, Esquivel CR, Watts KL, Zuo J. Cellular mechanisms of ototoxicity.FrontCellNeurosc. 2018;12(art 75):1-3. [Editorial]. 
Tachikawa E, Kudo K, Harada K, Kashimoto T, Miyate Y, Kakizaki A, Takahashi E. Effects of ginseng saponins on responses induced by various receptor stimuli. Eur J Pharmacol. 1999;369(1):23-32.

Tian C, Kim YH, Kim YC, Park KT, Kim SW, Kim YJ, Lim HJ, Choung YH. Korean red ginseng ameliorates acute 3-nitropropionic acid-induced cochlear damage in mice. Neurotoxicology. 2013;34:42-50.

Wang AM, Sha SH, Lesniak W ,Schacht J. Tanshinone (Salviae miltiorrhizae extract) preparations attenuate aminoglycosideinduced free radical formation in vitro and ototoxicity in vivo. Antimicrob Agents Chemother. 2003;47(6):1836-41.

Wang D, Lippard SJ. Cellular processing of platinum anticancer drugs. Nat Rev Drug Discov. 2005;4(4):307-20.

Watson N, Ding B, Zhu X, Frisina RD. Chronic InflammationInflammaging-in the Ageing Cochlea: A novel target for Future Presbycusis Therapy. Ageing Res Rev. 2017;(40):142-8.

Xiong M, He Q, Lai H, Huang W, Wang L, Yang C. Radix astragali injection enhances recovery from sudden deafness. Am J Otolaryngol. 2012a;33(5):523-7.
Xiong M, He Q, Lai H, Wang J. Astragaloside IV inhibits apoptotic cell death in the guinea pig cochlea exposed to impulse noise. Acta Otolaryngol. 2012b;132(5):467-74.

Xiong M, Lai H, He Q, Wang J. Astragaloside IV attenuates impulse noise-induced trauma in guinea pig." Acta Otolaryngol. 2011;131(8):809-16.

Xiong M, Zhu Y, Lai H, Fu X, Deng W, Yang C, He Q, Zheng $\mathrm{G}$. Radix astragali inhibits the down-regulation of connexin 26 in the stria vascularis of the guinea pig cochlea after acoustic trauma. Eur Arch Otorhinolaryngol. 2015;272(9):2153-60.

Zhai S, Fang Y, Yang W, Gu R, Han D, Yang S. Clinical investigation on the beneficial effects of the Chinese medicinal herb Gushen Pian on sensorineural deafness and tinnitus. Cell Biochem Biophys. 2013;67(2):785-93.

Received for publication on $05^{\text {th }}$ April 2018 Accepted for publication on $26^{\text {th }}$ December 2018 